\title{
Pemanfaatan Listrik Tenaga Surya Sebagai Penerangan Di Jalan Desa Pedukuhan Plumbon Banguntapan
}

\author{
Muhammad Abdus Shomad, Zuhri Nurisna 2 \\ 1. Prodi. Teknik Mesin Vokasi Universitas Muhammadiyah Yogyakarta \\ 2 Prodi. Teknik Mesin Vokasi Universitas Muhammadiyah Yogyakarta \\ Jalan Brawijaya Tamantirto, Kasihan, Bantul, Daerah Istimewa Yogyakarta 55183 \\ Email: abdusshomad@umy.ac.id \\ DOI: $10.18196 / p p m .32 .182$
}

\begin{abstract}
Abstrak
Krisis energi dunia dan tingginya harga sumber energi (minyak) di belahan dunia Eropa dan Barat menyebabkan inovasi dalam pemanfaatan energi alternatif yang tidak menimbulkan polusiudara $\mathrm{CO}_{2}$ dan radioaktif (nuclear power). Energi sel surya adalah jawaban tepat dalam menciptakan lingkungan hidup, lingkup perumahan, dan bangunan komersial yang ramah lingkungan dan abadi abadi. Kebutuhan akan energi listrik merupakan kebutuhan yang pokok, di samping kebutuhan sandang, pangan, dan papan. Energi listrik mutlak dibutuhkan oleh masyarakat untuk menunjang segala aktivitas keseharian. Tujuan dari pelaksanaan kegiatan pengabdian kepada masyarakat ini adalah untuk memberikan sebuah sumber energi listrik alternatif terbarukan dengan memanfaatkan panel solar cell yang dapat digunakan oleh masyarakat mitra di Pedukuhan Plumbon, Desa Banguntapan, Bantul, khususnya di lokasi Jalan Desa Pedukuhan Plumbon yang selama ini masih minim penerangan dan rawan terjadi tindak kejahatan. Metode yang diterapkan pada kegiatan pengabdian ini ialah menetapkan rencana, baik berupa diagram kerja, sistem, maupun alat. Hasil yang diperoleh adalah tersedianya energi listrik alternatif (solar cell) fasilitas penerangan sehingga dapat memberikan rasa aman kepada warga Pedukuhan Plumbon dan masyarakat lainnya yang setiap saat melintas di jalan desa tersebut.
\end{abstract}

Kata kunci: Energi alternatif, Panel solar cell, Plumbon, listrik tenaga surya

\section{Pendahuluan}

Banguntapan adalah sebuah desa yang terletak di Kecamatan Banguntapan, Kabupaten Bantul, Daerah Istimewa Yogyakarta, Indonesia. Kelurahan Banguntapan merupakan kelurahan dengan penduduk terbanyak dan tingkat ekonomi tertinggi di antara kecamatan lainnya di Kabupaten Bantul. Desa Banguntapan mempunyai garis bawah wilayah admisitrasi struktural sebelas pedukuhan. Masing-masing pedukuhan mempunyai jumlah penduduk yang berbedabeda. Kesebelas pedukuhan tersebut adalah 1) Tegaltandan, 2) Jaranan, 3) Jomblangan, 4) Wonocatur, 5) Karangjambe, 6) Karangbendo, 7) Sorowajan, 8) Plumbon, 9) Pelemwulung, 10) Pringgolayan, dan 11) Modalan. Pelaksanaan kegiatan pengabdian akan dilaksanakan di Dukuh Plumbon (Dusun Plumbon). Dusun ini merupakan dusun yang terletak di bagian utara dari Desa Banguntapan. Dusun ini terbagi dalam 34 RT dan 6 RW dengan luas $\pm 96,2$ hektare. Dusun ini berbatasan dengan Kota Yogyakarta di sebelah barat, Kota Yogyakarta di sebelah Selatan, Dusun Karangjambe sebelah timur, dan di sebelah utara berbatasan dengan Dusun Sorowajan.(Fauzi, M.,\& Winarni, F.,2018). Potensi unggulan Dusun Plumbon adalah bidang industri, yaitu produksi tas, batik, jahe wangi yang diproduksi oleh kelompok wanita tani, pengolahan makanan, dan souvenir. Selain itu, Dusun Plumbon juga memiliki potensi di bidang seni, yaitu karawitan,ruwahan, dan seni musik. Kegiatan lainnya adalah adanya gelar budaya dusun di setiap tahun. Jumlah Penduduk mencapai 3000 jiwa yang tercatat di database Pedukuhan Plumbon. Sekitar 25 persen dari jumlah kepala keluarga di huni oleh anak kos dan keluarga pengontrak rumah karena letak pedukuhan ini di kelilingi beberapa kampus perguruan tinggi sehingga kebanyakan yang tinggal di Dukuh VIII Plumbon adalah para mahasiswa. 
Dengan banyaknya jumlah pendukuk di Pedukuhan (dusun) Plumbon yang banyak dihuni oleh para pendatang dan mahasiswa kos, kondisi ini dapat mudah memicu tindak kejahatan di lingkungan Pedukuhan Plumbon. Beberapa tindak kejahatan yang sering terjadi di Pedukuhan Plumbon adalah tidak perampasan perhiasan, pemalakan uang terhadap warung makan yang buka selama 24 jam, terutama terjadi di pagi hari (sumber : data krimimal dipedukuhan plumbon 2018). Penerangan jalan yang masih minim ini merupakan faktor peluang pagi para perampas untuk melakukan aksinya. Dengan situasi penerngan yang masih minim, pelaku perampasan akan mudah untuk melakukan tindakan jahatnya (Widodo, A. 2009). Kesadaran warga dalam jaga malam (siskampling/sistem kemanan kampung keliling) belum dapat berjalan secara maksimal. Hal ini disebabkan warga belum peduli dengan kondisi yang ada dan kegiatan jaga malam hanya sekedar menggugurkan kewajiban jadwal saja. Akibatnya, belum terpenuhi kesadaran kolektif untuk mengamankan kampungnya sebagai tanggung jawab bersama. Hal inilah mengakibatkan Dusun Plumbon rawan tindak kejahatan. Selain itu juga belum ada alat pemantau keamanan (CCTV) di titik yang dianggap rawan karena belum didukung ketersediaan alat tersebut.(Fauzi, M.,\& Winarni, F.,2018)

Metode Pelaksanaan

Pemecahan permasalahan pemanfaatan listrik tenaga surya sebagai penerangan jalan Dusun Plumbon dilakukan dengan pendekatan bersama-sama bisa dilihat seperti pada Gambar 1. 


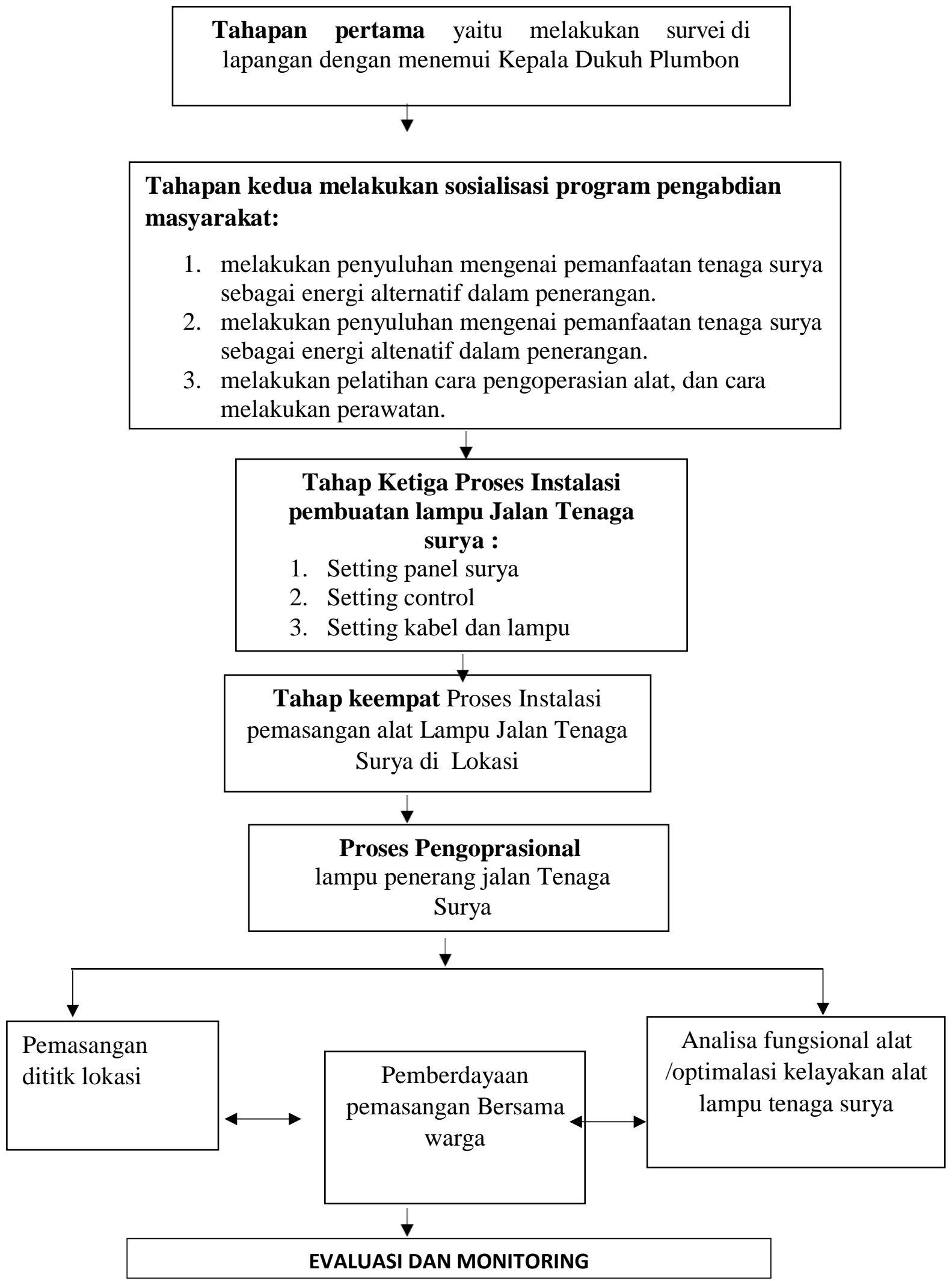

Gambar 1. Langkah - Langkah Metode Pelaksanaan Pengabdian Masyarakat Penerapan Lampu Jalan Bertenaga Surya 
Program kegiatan ini dilaksanakan dalam beberapa metode, antara lain

a. Observasi dan pemetaan lokasi titik pasang lampu

Observasi dilakukan di wilayah RT 12 setempat di Pedukuhan Plumbon, yaitu di jalan penghubung antarpedukuhan. Jalan penghubung tersebut menghubungkan Pedukuhan Plumbon dan Karangjambe dan Kanoman yang semuanya masuk dalam wilayah jalan Desa Banguntapan. Pelaksanaan observasi dilakukan dengan cara wawancara pada segenap komponen masyarakat, seperti Kepala Pedukuhan Plumbon dan warga masyarakat. Selain itu, observasi juga dilakukan dengan melihat kondisi lapangan secara langsung. Pemetaan ini untuk memperjelas keadaan dan karakteristik pedukuhan ini terkait kebutuhan peneranagan jalan. Pemetaan ini dapat dijadikan sebagai acuan untuk menentukan langkah selanjutnya.

b. Sosialisasi

Sebelum pelaksanaan seluruh rangkain kegiatan pengabdian masyarakat ini dimulai, perlu diadakan sosialisasi mengenai program ini kepada Ketua RT 14, Ketua RT dan RW, BPD Kelurahan Desa Banguntapan, Kepala Pedukuhan setempat, dan masyarakat. Tujuan kegiatan ini adalah agar masyarakat memahami program tersebut dan tidak terjadi kesalahpahaman dalam pelaksanaan program. Selain itu, sosialisasi juga berfungsi untuk menggali lebih dalam mengenai permasalahan yang dialami masyarakat dan solusi yang dibutuhkan. Dengan begitu, diharapkan program pengabdian masyarakat ini dapat menghasilkan luaran yang sesuai dengan keinginan dan kebutuhan masyarakat.

c. Lokasi Pelaksanaan

Lokasi pelaksanan program ini adalah di wilayah Pedukuhan Plumbon, Desa Banguntapan, tepatnya di RT Kecamatan Banguntapan, Kabupaten Bantul, Daerah Istimewa Yogyakarta.

d. Pelaksanaan Program

Rangkaian kegiatan program pengabdian masyarakat yang akan dilakukan mencakup beberapa tahap:

1. Perhitungan kebutuhan lampu penerangan jalan tenaga surya

Dalam kegiatan ini dilakukan penghitungan/survei lokasi kebutuhan penerangan berdasarkan kondisi dan situasi lingkungan. Setelah melakukan survei di lapangan dan analisis situasi, dipastikan lokasi/lingkungan yang perlu dipasang lampu penerang jalan tenaga surya, yaitu di RT 14 Plumbon.

2. Pelaksanaan pembuatan alat lampu penerang jalan bertenaga surya

Pelaksanaan pembuatan alat lampu penerang jalan bertenaga surya terdiri atas instalasi panel surya, instalasi kontrol lampu, instalasi letak dan arah panel surya yang dipasang ke tiang besi.

3. Evaluasi dan tindak lanjut

Evaluasi dilakukan untuk mengetahui seberapa efektif program ini dan seberapa besar manfaat atau kontribusinya kepada masyarakat. Tindak lanjut program ini sangat diperlukan untuk menjamin keberlangsungan program keamanan dan kanyamanan jalan desa penghubung antarpedukuhan bagi warga.

\section{Hasil dan Pembahasan}

\section{Hasil Pengabdian Masyarakat}

a. Survey Lokasi 
Kegiatan pengabdian masyarakat ini dilaksanakan di Pedukuhan Plumbon, Desa Banguntapan, Kecamatan Banguntapan, Kabupaten Bantul, Yogyakarta. Sebagaimana ditunjukkan pada gambar 1 dan gambar 2, kegiatan diawali dengan survei lokasi/penentuan titik pemasangan lampu jalan tenaga surya dan sosialisasi program seperti yang terlihat pada gambar 2 dan 3. Kondisi situasi lingkungan yang jauh dari jaringan listrik membuat kondisi situasi jalan di malam hari dalam keadaan gelap sehingga masyarakat yang melewati jalan tersebut merasa tidak nyaman. Di jalan tersebut pernah beberapa kali terjadi tindak kriminal yang menyebabkan masyarakat merasa was-was dan tidak tenang.
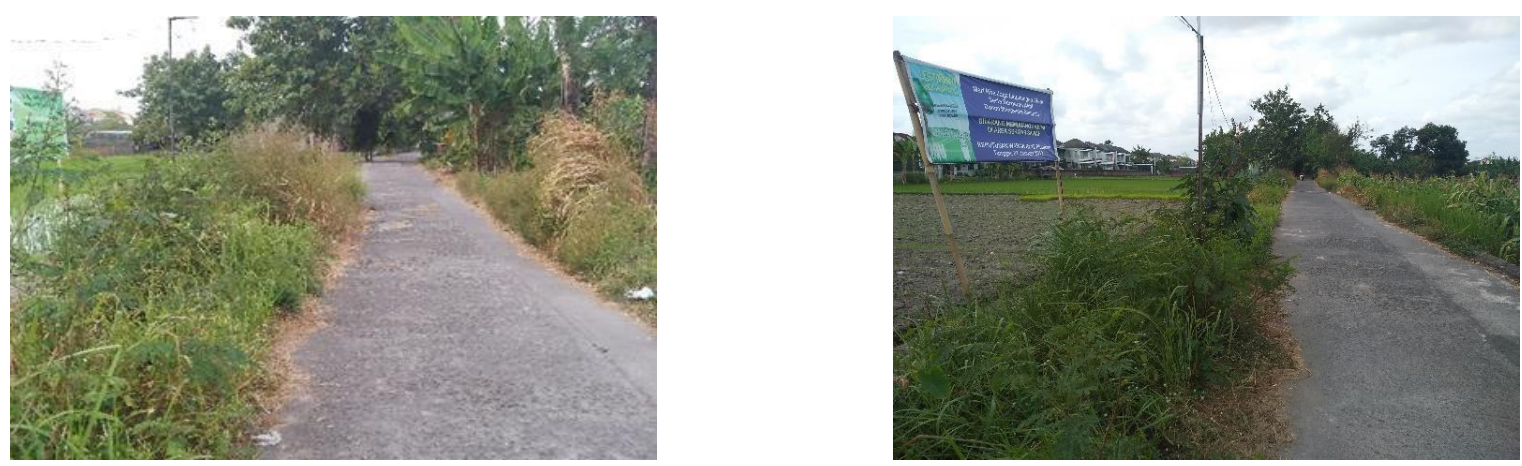

Gambar 1. Lokasi Pemasangan Lampu jalan Tenaga Surya
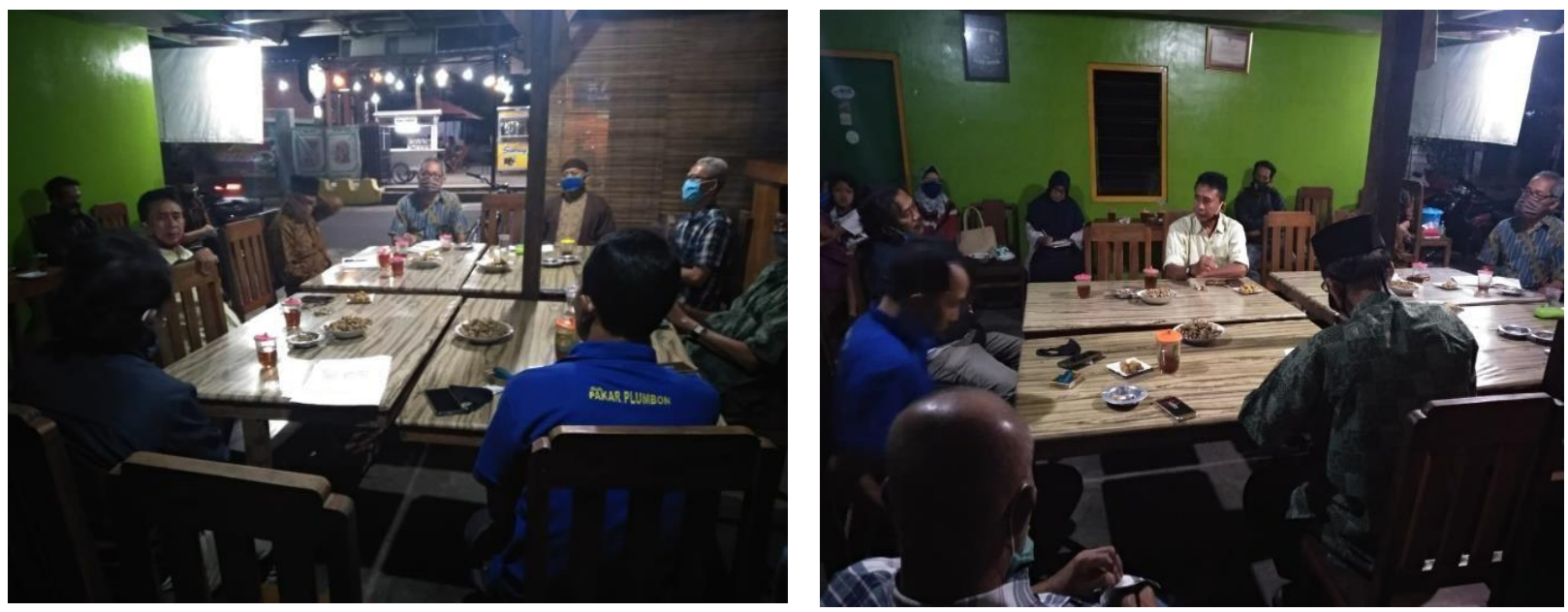

Gambar 2 Sosialisasi Program Pengabdian Masyarakat

b. Kegiatan Sosialiasi Program

Sosialisasi kegitan program pengabdian masyarakat seperti telihat pada gambar 2 ini dibagi menjadi beberapa tahap. Tahap pertama yaitu sosialisasi pengenalan program pengabdian masyarakat dengan pejabat pedukuhan dan warga. Tahap kedua adalah sosialiasasi mengenai energi tenaga surya dan pemanfaatannya. Sosialisasi ketiga yaitu mengenai proses pemasangan di daerah titik yang akan dilaksanakan. Dari beberapa tahap sosialaisi yang dilakukan selalu mendapat respon yang baik dan positif. Hal ini dapat terlihat dari jumlah warga yang mengikuti kegitan tersebut. 
c. Prinsip Kerja Lampu Penerangan Jalan Bertenaga Surya

Lampu jalan tenaga surya bekerja berdasarkan prinsip sel surya atau sel fotovoltaik untuk menyerap energi matahari di siang hari. Sel fotovoltaik mengubah energi matahari menjadi energi listrik. Energi matahari yang dikonversi disimpan dalam baterai. Lampu jalan panel surya menggunakan energi matahari. Saat ini lampu jalan panel surya tersedia di sepanjang jalan. Pada malam hari lampu menyala secara otomatis dan menggunakan energi listrik yang disimpan dalam baterai. Setiap hari proses ini berlanjut.
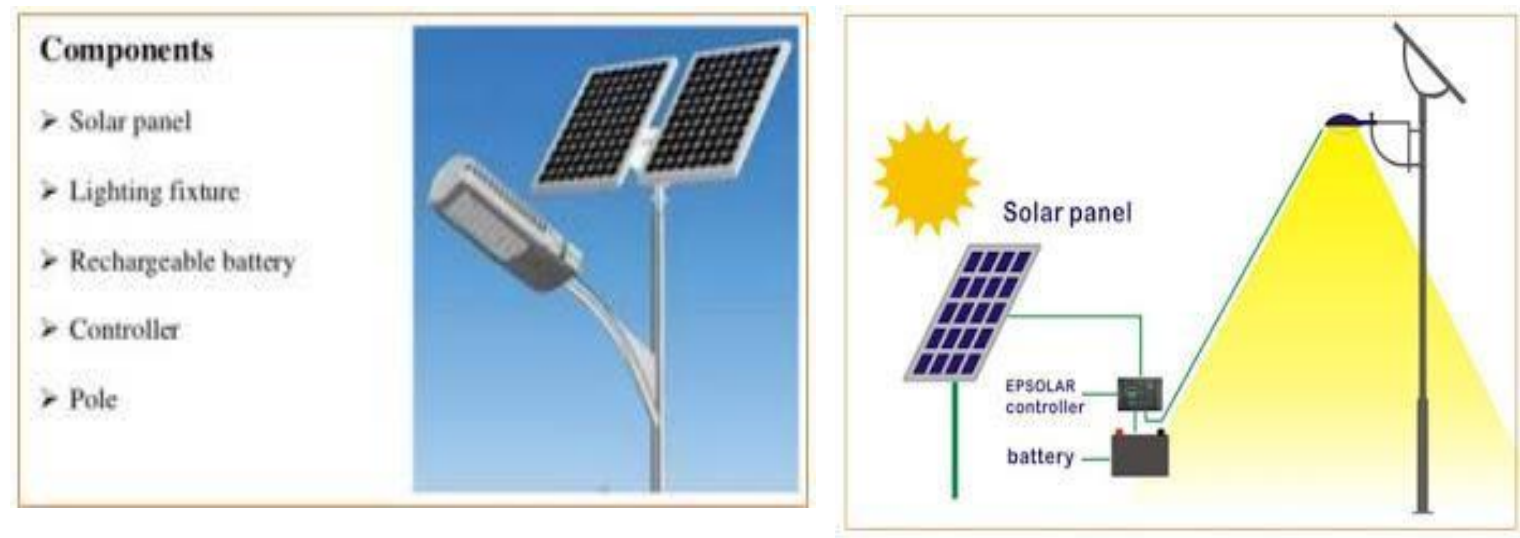

Gambar 3 . Skema gambar lampu jalan tenaga surya
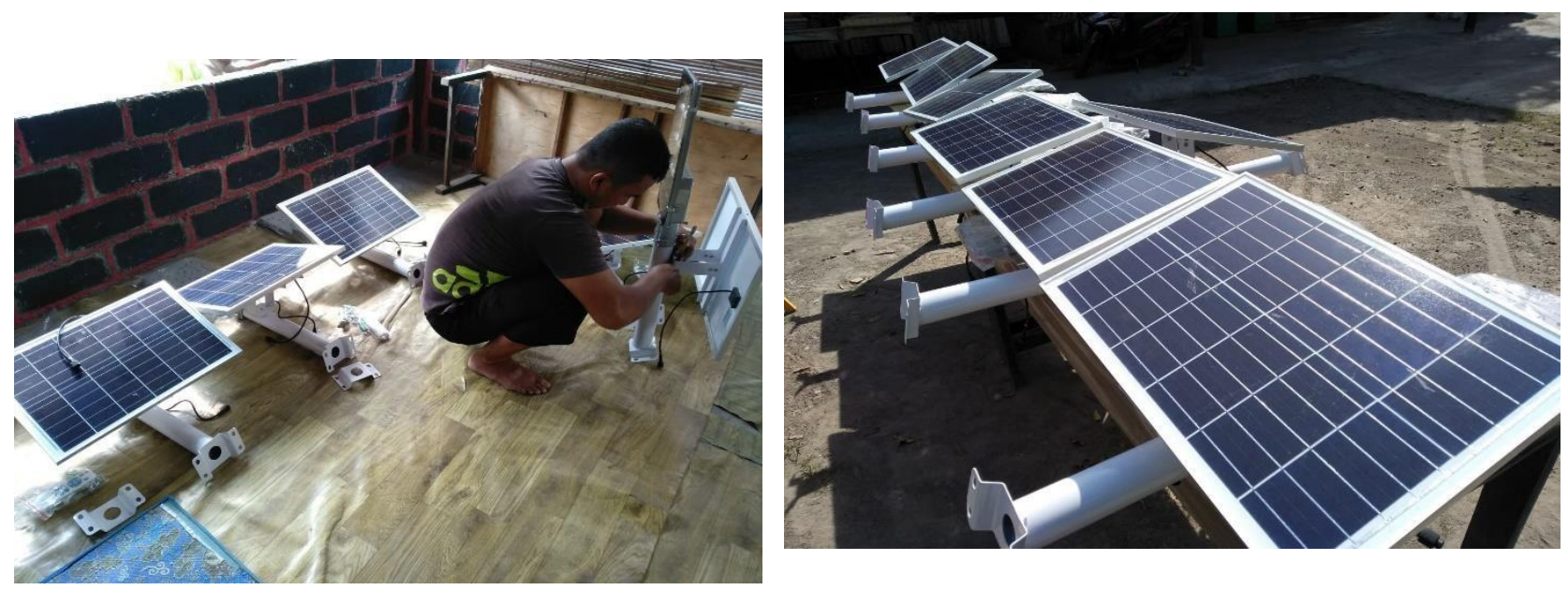

\section{Gambar 4 instalasi panel surya}

Seperti terlihat pada gambar 4, proses instalasi lampu tenaga surya dilakukan oleh warga yang telah dilatih untuk melakukan perakitan instalasi lampu penerangan jalan tenaga surya. Oleh karena itu, hasil yang didapat dapat berfungsi dengan baik sebagai mestinya. 

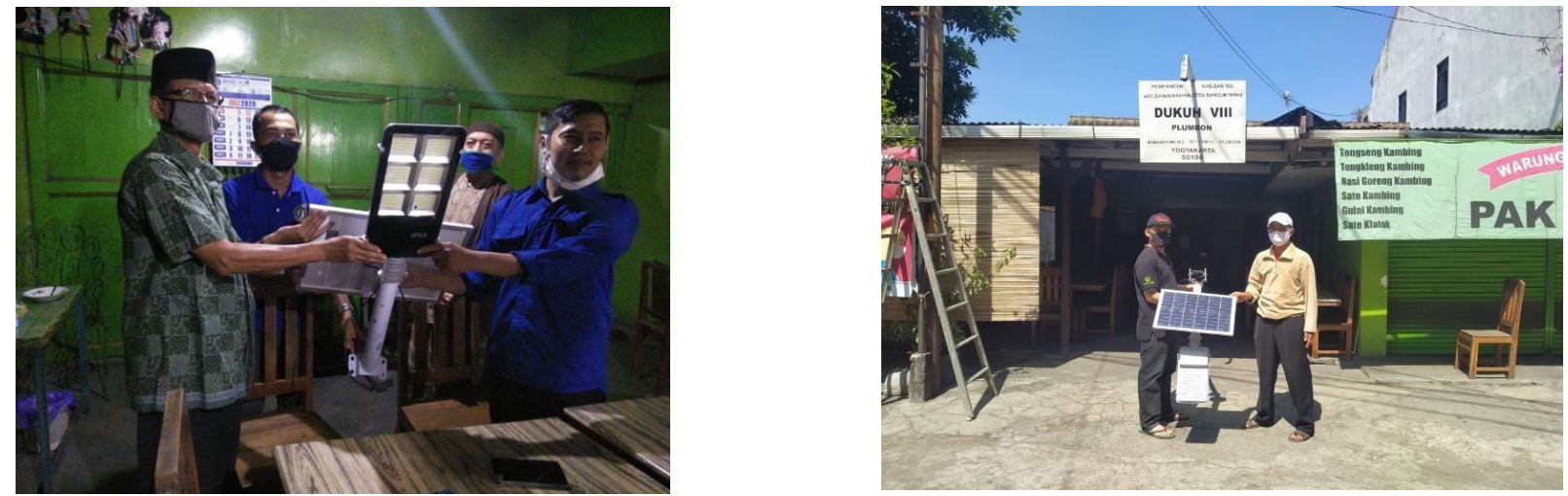

Gambar 5 Penyerahan lampu Penrangan jalan Tenaga surya

Pada gambar 5, dapat dilihat proses penyerahan lampu penerang jalan tenaga surya yang telah selesai dilakukan proses instalasi dan siap untuk dipasang. Secara simbolis, penyerahan diterima oleh ketua BPD (Badan perwakilan Desa) Banguntapan dan disaksikan oleh Kepala Pedukuhan Plumbon dan ketua RT dan RW.
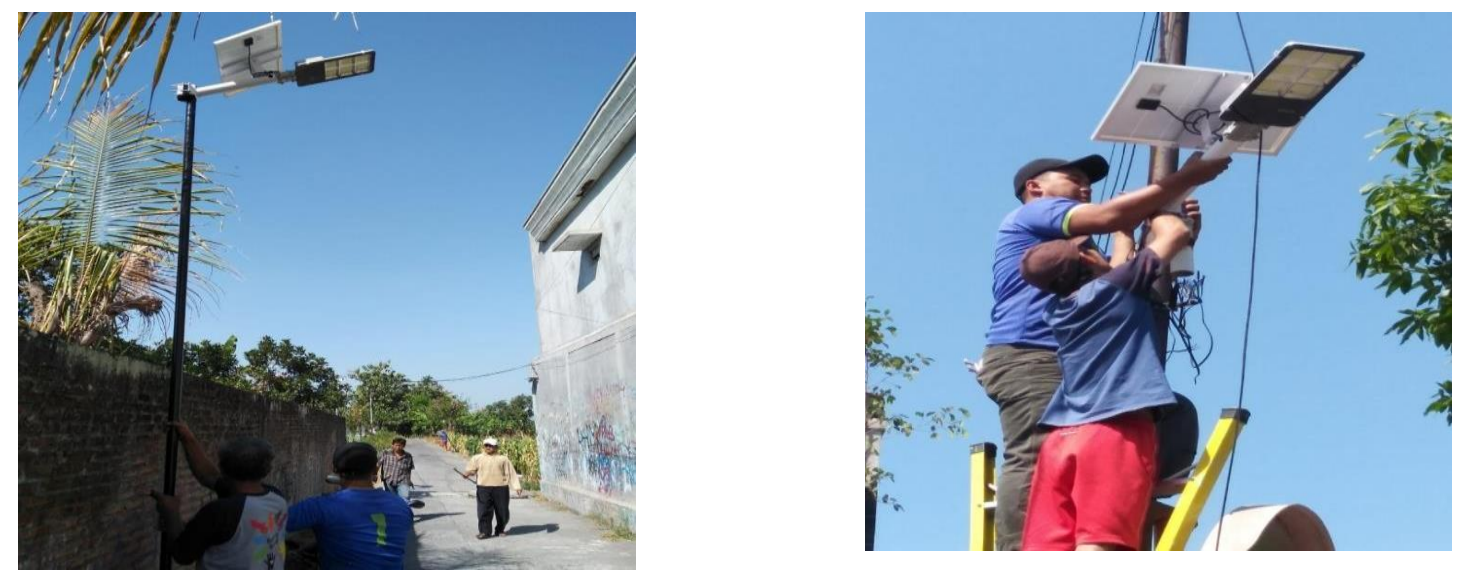

Gambar 6 Pemasangan lampu penernag jalan tenaga surya
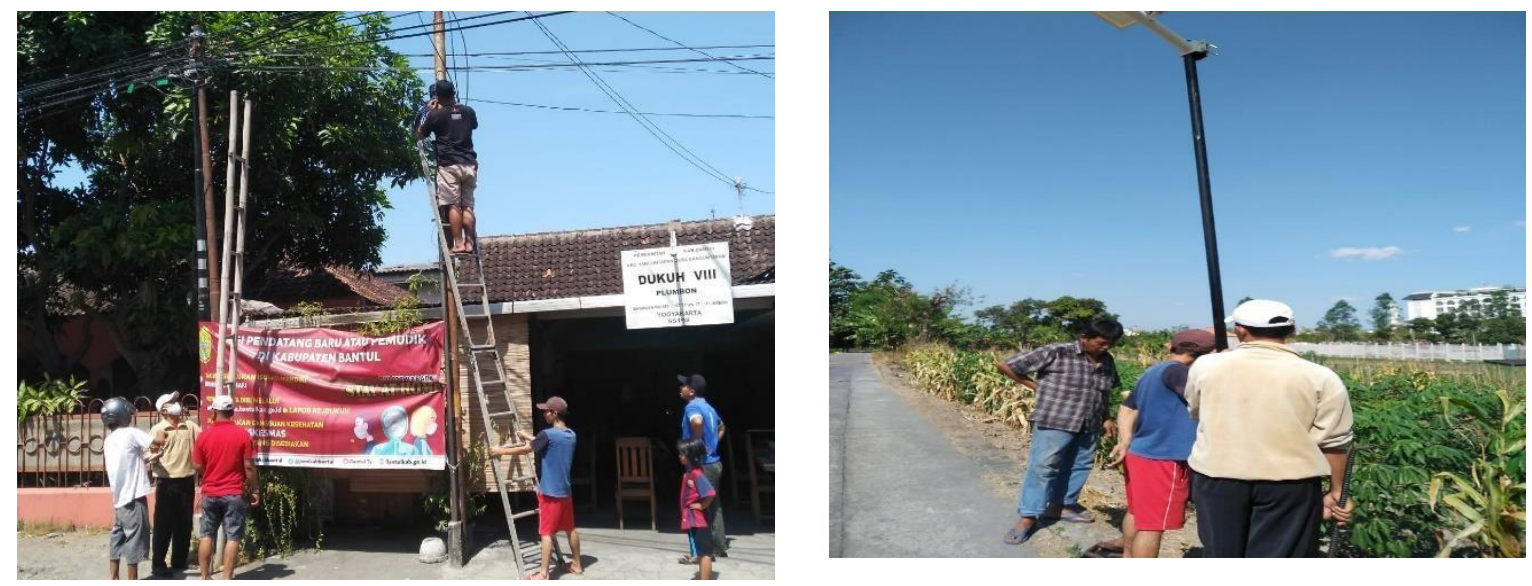

Gambar .7 Pemberdayaan masyarakat pemasasangan lampu penernag jalan ternaga surya 
Seperti yang terlihat dalam gambar 6 dan 7, proses pemasangan lampu penerangan tenaga surya dilaksanakan bersama warga secara gotong-royong. Hal ini menunjukkan peran pemberdayaan masyarakat berjalan dengan baik. Warga pun antusianya melaksanakan kegiatan ini. Pelaksanaan pengabdian mendapat perhatian yang baik dari masyarakat Plumbon. Dari hasil pemetaan, sejak awal memang lokasi ini benar-benar membutuhkan penerangan. Dari hasil laporan Kepala Pedukuhan Plombon, di lokasi jalan tersebut sering terjadi tindak kejahatan kriminal.

Tahapan Metode Sosialiasi dan Penyuluhan Pelaksanaan

1. Tahapan pertama, yaitu melakukan survei di lapangan dengan menemui kepala dukuh

2. Tahapan kedua, yaitu melakukan sosialisasi program pengabdian masyarakat

3. Tahapan ketiga, yaitu melakukan penyuluhan mengenai pemanfaatan tenaga surya sebagai energi altenatif dalam penerangan.

4. Tahapan keempat, yaitu melakukan pelatihan cara pengoperasian alat dan cara melakukan perawatan.

5. Tahapan kelima, yaitu pendampingan kepada kedua mitra untuk melakukan operasional alat lampu penernagan jalan bertenaga surya.

6. Tahapan keenam, yaitu melakukan evaluasi dan monev setelah pemasangan lampu penerangan jalan bertenaga surya.

7. Tahapan ketujuh, yaitu melakukan analisis hasil evaluasi dan monev untuk tidak lanjut dari program pengabdian masyarakat dengan melakukan kajian serta saran-saran mitra untuk langkah tidak lanjut dari program pengabdian masyarakat.

\section{GAMBARAN IPTEK}

\section{Solar Cell}

Solar cell atau panel surya adalah alat untuk mengonversikan tenaga matahari menjadi energi listrik (Salam, Z., Ishaque, K., \& Taheri, H.,2010, December). Photovoltaic adalah teknologi yang berfungsi untuk mengubah atau mengonversi radiasi matahari menjadi energi listrik secara langsung. Photovoltaic biasanya dikemas dalam sebuah unit yang disebut modul. Dalam sebuah modul surya terdiri atas banyak sel surya yang bisa disusun secara seri dan paralel. Sementara yang dimaksud dengan surya adalah sebuah elemen semikonduktor yang dapat mengonversi energi surya menjadi energi listrik atas efek photovoltaic. Solar cell dapat dilihat pada Gambar 8.
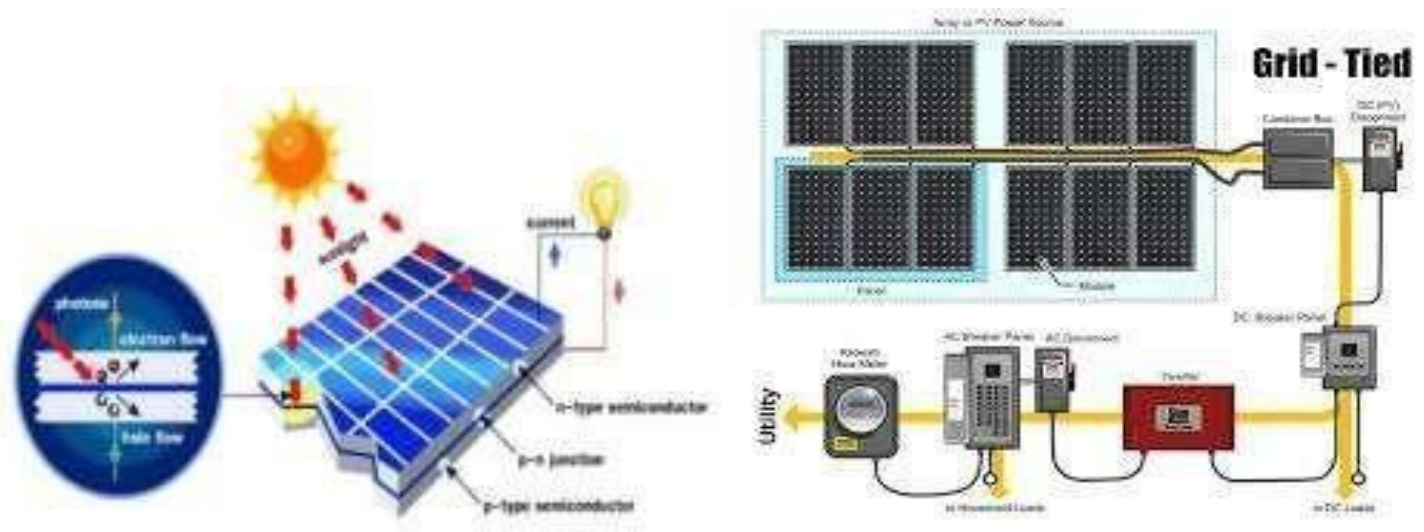

Gambar 8. Skema Solar Cell

(Sumber: http://trebuchet-magazine.com/wp-content/uploads/2013/02/solar-cells.jpg) 

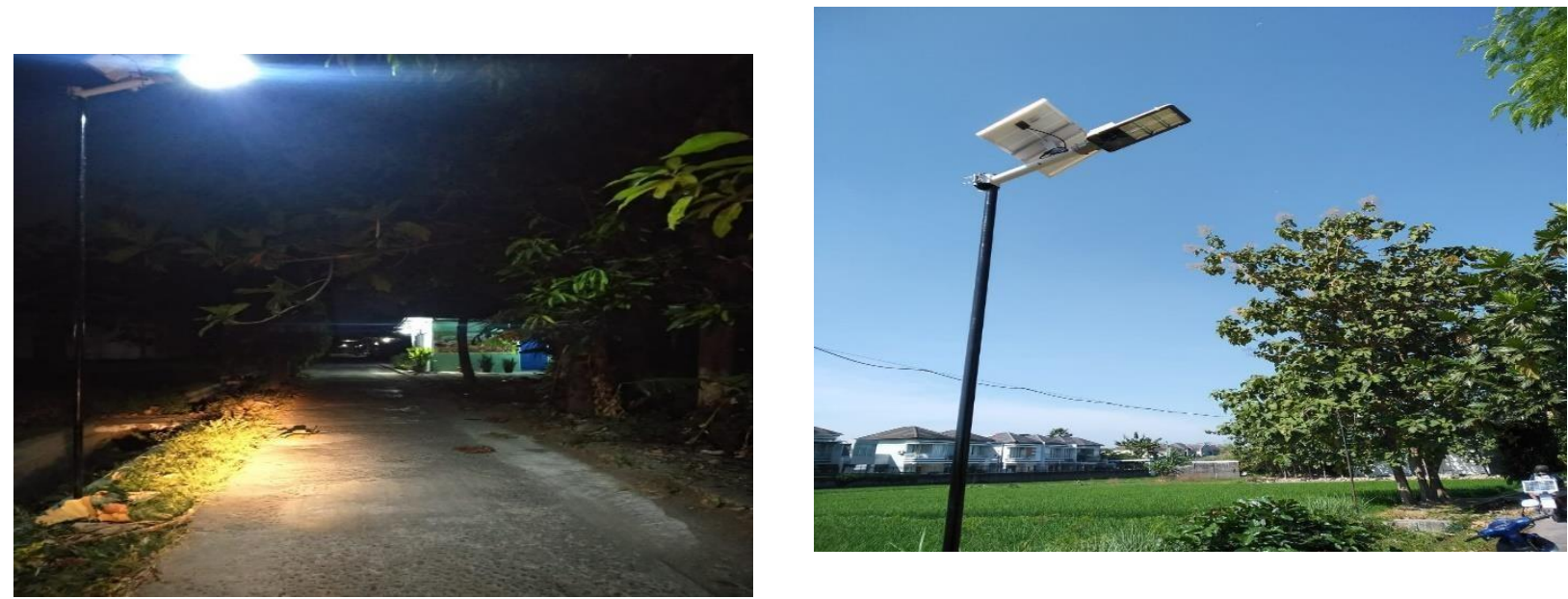

Gambar 9 Setelah lampu jalan ternaga surya dipasang

\section{Penerapan Alat}

Penerapan alat ditunjukkan pada gambar 9. Pada gambar 9 terlihat satu set lampu jalan tenaga surya yang terdiri atas lampu led $45 \mathrm{w}$, panel surya $50 \mathrm{wp}, 1$ set control charger, sensor otomatis mati dan hidup. Pada gambar 9 realistas pemasangan menunjukkan bahwa jalan desa penghubung Pedukuhan Plumbon, Kanoman dan Karangbendo awalnya tidak ada lampu jalan, dalam kondisi gelap. Setelah dilakukan pemasangan alat penerangan jalan tenaga surya, jalan desa di RT 12 Pedukuhan Plumbon mendapat penerangan yang cukup.

\section{Simpulan}

Hasil program pengabdian yang telah dilaksanakan, secara umum berjalan dengan lancar. Warga menyambut dengan baik dan antusias. Suasana lokasi awalnya gelap dan kurang pencahayaan. Setelah dilakukan pamasangan lampu penerangan jalan, situasi dan kondisi lingkungan bertambah terang.

\section{Ucapan Terimakasih}

Keberhasilan pelaksanaan kegiatan program pengabdian masyarakat (PKM) merupakan hasil dukungan, kerja sama, dan dorongan berbagai pihak. Untuk itu, selaku tim pelaksana, kami menyampaikan terima kasih dan penghargaan yang setinggitingginya kepada LP3M UMY dan mitra yang selama kegiatan memberikan dukungan yang positif, baik material maupun non material.

\section{DAFTAR PUSTAKA}

Ardianto, R., Nugroho, W. A., \& Sutan, S. M. (2015). Uji Kinerja Dye Sensitized Solar Cell (DSSC) Menggunakan Lapisan Capacitive Touchscreen Sebagai Substrat dan Ekstrak Klorofil Nannochloropsis Sp. Sebagai Dye Sensitizer dengan Variasi Ketebalan Pasta TiO2. Jurnal Keteknikan Pertanian Tropis dan Biosistem, 3(3), 325-337.

Fahmi, F. (2016). Penyalahgunaan Fungsi Tanah Kas Desa di Kecamatan Banguntapan Kabupaten Bantul Daerah Istimewa Yogyakarta (Doctoral dissertation, Universitas Islam Indonesia).

Fauzi, M., \& Winarni, F. (2018). Efektivitas Program Pemberantasan Sarang Nyamuk Melalui Gertak Psn Di Desa Banguntapan Kecamatan Banguntapan, Bantul. Adinegara, 7(4), 443457. 
Kumara, K. V., Kumara, I. N. S., \& Ariastina, W. G. (2018). Tinjauan Terhadap PLTS 24 kW Atap Gedung PT Indonesia Power Pesanggaran Bali. Jurnal SPEKTRUM, 5(2), 26- 35.

Laksono, A. B., \& Zahidi, A. R. Z. (2017). Rancang Bangun Alat Pengusir Burung Pemakan Padi Berbasis Mikrokontroller Atmega328 Dengan Sel Surya. Fakultas Teknik, Elektro Universitas Islam Lamongan.

Supriadi, E. (2015). Pertanggungjawaban Kepala Desa dalam Pengelolaan Keuangan Desa Berdasarkan Undang-Undang Nomor 6 Tahun 2014 Tentang Desa. Jurnal IUS Kajian Hukum dan Keadilan, 3(2).

Sidopekso, S., \& Febtiwiyanti, A. E. (2010). Studi peningkatan output modul surya dengan menggunakan reflektor. Berkala Fisika, 12(3), 101-104.

Salim, A. T. A., \& Indarto, B. (2018). Studi Eksperimental Karakterisasi Elemen Termoelektrik Peltier Tipe TEC. JEECAE (Journal of Electrical, Electronics, Control, and Automotive Engineering), 3(1), 179-182.

Salam, Z., Ishaque, K., \& Taheri, H. (2010, December). An improved two-diode photovoltaic (PV) model for PV system. In 2010 Joint International Conference on Power Electronics, Drives and Energy Systems \& 2010 Power India (pp. 1-5). IEEE.

Suhardi, D. (2015). Prototipe Sel Surya Berbahan Tembaga Oksida (Cuo) dan Seng Oksida (Zno) dengan Dielektrikum H2SO4. Jurnal Gamma, 9(1).

Utari, E. L. (2018). Penyuluhan \&Aplikasi Energi Terbarukan (Solar Cell) Guna Memenuhi Kebutuhan Energi Alternatif Pengganti Listrik Di Wilayah Dusun Nglinggo Kelurahan Pagerharjo Kecamatan Samigaluh Kabupaten Kulon Progo. Jurnal Pengabdian Dharma Bakti, 1(1).

Wiryadinata, R., \& Munarto, R. (2013). Studi Pemanfaatan Energi Matahari Di Pulau Panjang Sebagai Pembangkit Listrik Alternatif. Setrum: Sistem Kendali-Tenaga- ElektronikaTelekomunikasi-Komputer,2(1),6-15.

Wananda, N. (2019). Analisa Perbandingan Optimasi Pengisian Daya Baterai (ACCU) Pada PLTB dan PLTS Menggunakan Solar Charger Controller Tipe PWM dan MPPT (Doctoral dissertation).

Widodo, A. (2009). Kajian Manajemen Optimalisasi Penerangan Jalan Umum Kota Semarang. Jurnal Teknik Sipil dan Perencanaan, 11(1), 41-50.

Yau, H. T., Lin, C. J., \& Liang, Q. C. (2013). PSO based PI controller design for a solar charger system. The Scientific World Journal, 2013. 